\title{
LegalTech in Law Firms and the Work of In-house Lawyers
}

\author{
Iga Kurowska, Kamil Szpyt
}

\section{Introduction}

Law offices and offices of in-house lawyers seem to be the first place where - in all likelihood - you will come across the practical application of LegalTech solutions. Unlike public administration bodies whose innovation may be limited by lack of adequate funding or unnecessary bureaucracy, attorneys - as the representatives of the private sector driven by the free market economy - should strive to provide service at the highest possible level.

This, however, is just a theory. The reality, unfortunately, is quite different. It should be remembered that the vast majority of entities in the legal sector present on the market are not large corporations with impressive capital but one-person or several-person law firms, usually employing only the indispensable administrative staff. With such a balance of power, it is difficult for the aforementioned lawyers to find both the time and the resources to invest in implementing innovative technological solutions that - with fair winds - will pay off only after a longer period of use ${ }^{1}$.

Theoretically, so-called in-house lawyers - employed in large pharmaceutical, telecommunication, insurance companies, etc. - should be in a better situation. In their case, the costs of purchasing and implementing of new IT systems and software are usually borne by the employer/principal. This, in turn, involves the necessity of requesting consent for such actions, which may often be refused. Thus, the scope of freedom of decision in the case of these employees is significantly limited. In addition, there has recently been a widespread tendency to reduce the budgets of legal depart-

1 It should be pointed out, however, that there are also opinions that in the case of smaller law firms it is easier to decide to implement new, previously unused solutions; see: Tomasz Zalewski, 'LEGALTECH - wyzwanie przyszłości' (2019) 3 Temidium 9. 
ments, even though - given the circumstances described in this chapter this issue should rather look quite different ${ }^{2}$.

Nevertheless, after the above somewhat pessimistic introduction, it should be pointed out that the situation of using LegalTech solutions in the legal services market does not look bad at all. They are becoming increasingly popular not only among large corporations, but also smaller law firms. It also seems that lawyers are increasingly willing to experiment and take the financial risk of implementing new solutions ${ }^{3}$. This is often the case when client expectations require so. However, this does not change the fact that, unfortunately, the process may involve numerous complications, which - at the very beginning - may be ignored by enthusiastic lawyers. On the other hand, in the doctrine, there is still a considerable gap as regards publications that could constitute a guide and introduction to the issues in question, which means that many lawyers have to make their adventure with LegalTech through trial and error, many of which could be avoided.

The above circumstances led to writing this chapter in an attempt to answer the question: what LegalTech solutions actually are or should be used by lawyers working in law firms and in-house lawyers ${ }^{4}$. The authors have refrained from discussing specific products available on the market in order to achieve the greatest possible universality of the present study. Such generalisation, due to the market's dynamic, will also guarantee the text to preserve its relevance ${ }^{5}$. In addition, for the sake of clarity of

2 See Mateusz Jakubik and Tomasz Świetnicki, 'Technologia coraz bardziej obecna w pracy prawników' <www.prawo.pl/prawnicy-sady/informatyka-w-pracy-prawnik ow-eksperci-pisza -o-legal-tech,504169.html> accessed 25 April 2021.

3 However, it should be noted that the level of development of the LegalTech market in individual EU countries will vary. In some of them, similar solutions are slowly becoming a standard (France, Spain). In other countries, the market is just beginning to develop (e.g. Poland); see Maciej Wróblewski, 'Gdzie zaczęła się LegalTechowa rewolucja?', <https://blockchainext.io/gdzie-zaczela-sie-legaltechowa -rewolucja-wywiad/> accessed 25 April 2021.

4 Due to the fact that, despite appearances, the work of lawyers employed in law firms in many areas differs significantly from the activity of in-house lawyers, which also translates into LegalTech solutions recommended for and used by these groups, it was necessary in many places of this article to limit itself to relatively general considerations, since undertaking a more detailed analysis, detailing the differences in both cases, would go far beyond the scope of this chapter.

5 This decision was all the more obvious for the authors of this chapter, as the Internet offers rankings or entire databases of LegalTech products, often grouped according to their functions - see, e.g.:. Katalog LegalTech available on Fundacja 
the argument, it was done taking into account the three-level division of LegalTech ${ }^{6}$ presented in the first chapter.

\section{LegalTech 1.0}

\subsection{The Most Popular Tools}

At the beginning of this discussion, it is worth pointing out that the elementary set of computer tools categorized as LegalTech 1.0 and used in everyday work of in-house and office lawyers includes software for word processing, organizing data in spreadsheets and preparing visual presentations. The tools which nowadays have an equally wide range of applications are: electronic mail, which continues to be the basis for both external and internal communication as well as video and teleconferencing tools (which gain increasing popularity as a result of the COVID-19 pandemic and travel restrictions associated therewith). Automated invoicing software can also be included in the array of commonly used solutions. Lawyers also seem to be taking more and more advantage of e-signature and public administration platforms. Although it is difficult to predict that all EU countries will introduce paperless solutions in the coming years, filing official documents in an electronic form or conducting court hearings online (although, not yet fully accepted by the entire legal community) is no longer seen as something unusual.

The above solutions have been widely implemented by almost all law firms and in-house lawyers. The implementation of these solutions is natural and not associated with major concerns or difficulties in application, except perhaps for some practical problems, however, resulting more from the slow digital transformation of public institutions rather than law firms handling lawsuits. Let us not forget, however, that obstacles of a similar nature, i.e. lengthy procedures, difficulties in communication and

LegalTech Polska website <https://legaltechpolska.pl/katalog-legaltech-polska/> accessed 25 April 2021.

6 Oliver Goodenough, 'Getting to Computational Jurisprudence 3.0' in: Oliver Goodenough, Amedeo Santosuosso and Marta Tomasi (eds.), 'The Challenge of Innovation in Law: The Impact of Technology and Science on Legal Studies and Practice' (Pavia University Press 2015), 3.

7 The division into subsections introduced in this chapter is highly conventional in nature and its purpose is to allow the reader to more easily navigate through its contents rather than to set rigid boundaries between different solutions. 
technical problems, have been the concern of the justice system for many years ${ }^{8}$. Therefore, it would be wrong to expect that the use of new technologies alone would result in the removal of these obstacles. LegalTech, in the broad sense of the term, is only a part of improving legal work and systems; its application should therefore go hand in hand with the modernization of structures and management methods of organizations (whether we are talking about the private or the public sector).

Among LegalTech 1.0 tools which are intended to support lawyers in their daily work, making it faster, better and, consequently, more competitive $^{9}$, we can also mention the use of legal information platforms (systems) designed to collect judgments and doctrinal studies in a dematerialized form. They are usually available in the Software as a Service (SaaS) mod$\mathrm{el}^{10}$, sometimes divided into modules, each of them charged separately. Access to these tools seems to be a commonly recognized standard of equipment for every law firm and in-house lawyer.

\subsection{Best Practices in Omplementing LegalTech 1.0 Solutions.}

When discussing the use of technology in improving the work of lawyers, it is important to mention that part of a law firm's digital transformation should also include, in addition to the monitoring of the LegalTech market and introducing new IT solutions, an attempt to make the widest and safest use of the technological solutions (already possessed by a law firm or

8 See 'Diagnoza stanu polskiego sądownictwa. Materiał RPO dla sejmowego zespołu ekspertów „okrągłego stołu” <www.rpo.gov.pl/pl/content/diagnoza-sa downictwa-material-rpo-dla-sejmowego-zespolu-ekspertow $>$ accessed 25 April 2021.

9 As of 2019, the average lawyer invoices only 2.5 hours of work per day; see: 'Legal Trends Report 2019' (Clio 2019) <https://www.clio.com/wp-content/uploads/ 2019/10/2019-Legal-Trends-Report.pdf $>$ accessed 25 April 2021.

10 For more on SaaS contracts, see Michał Modrzejewski, 'Podatkowe aspekty korzystania z oprogramowania komputerowego w modelu SaaS (Software as a Service)' (2016) 8 Przegląd Podatkowy15; Krzysztof Żok, 'Prawna i ekonomiczna analiza umowy o korzystanie z programu komputerowego jako usługi (Software as a Service, SaaS)' (2017) 4 Zeszyty Naukowe Uniwersytetu Jagiellońskiego 63; Krzysztof Żok, 'Kwalifikacja umowy o korzystanie z programu komputerowego jako usługi (Software as a Service, SaaS) - uwagi na tle prawa polskiego i wybranych zagranicznych systemów prawnych' (2015) 3 Zeszyty Naukowe Uniwersytetu Jagiellońskiego 18. 
legal department) possible for all lawyers and administrative staff. In this context, it is particularly important to take care of two issues:

1) a high level of competence in training lawyers and administrative staff using LegalTech solutions - for example, adequate proficiency in using apparently simple and obvious word processing functions, such as change tracking, document comparison, automatic creation of tables of contents, footnotes, bibliographies, or keyboard shortcuts, can positively affect the efficiency of a law firm's work. Moreover, spreading the word about the licenses purchased by your law firm and familiarizing your team with the capabilities of the tools possessed as well as their upgrades (i.e. permitted new functionalities) is an important part of changing your work culture. Unfortunately, lawyers (focused on their day-to-day activities under time pressure), find it difficult to develop new habits and appreciate the importance of training to take full advantage of the capabilities of even the simplest legal technologies;

2) compatibility, legality and update of software used - however improbable it may seem, it is quite common for employees of smaller law firms to use software from an illegal source, used in violation of the principles of a license, or in trial versions. It is not uncommon for people working in a law firm to use their own (non-corporate) equipment (e.g. laptops), which they take home after work and use for private purposes; they often install software by downloading files from unverified sources.

The consequences of such behavior may be numerous and diverse in nature, including legal (e.g., use of software without a license or in violation of its rules) and organizational (incompatible versions of a file developed by a group of people in a law firm resulting in wasted time). However, it is particularly important to ensure compliance with cybersecurity rules ${ }^{11}$. As the coronavirus pandemic shows ${ }^{12}$, the use of new technologies contributes to the increase of risks related to network security and data processing. This is directly related to more frequent work at home and an increase in the amount of software used.

The key issue to which attention should be paid with regard to the above is the introduction of appropriate procedures and good practices for

11 See Section V Chapter 26.

12 See Violet O'Gorman, 'Cybercrime during the coronavirus pandemic: what does it mean for the legal industry?' < https://www.lexisnexis.co.uk/blog/in-house/cyber crime-during-the-coronavirus-pandemic-what-does-it-mean-for-the-legal-industry> accessed 25 April 2021. 
keeping software up to date. This is especially important for the operating system and the elementary tools used (in principle) on a daily basis: the web browser and the antivirus program. If possible, automatic software updates or at least an alert should be set up to notify about the availability of a new update. All sorts of background programs designed for updating and maintaining operating systems, usually equipped with a built-in function of informing about a potential vulnerability in the software and the possibility of mitigating it by installing an update will be particularly helpful for more careless users.

The above issue should be regulated in the IT system management instruction applicable in a given entity. All employees should become familiar with its content. The adoption and observance of such instruction in the workplace shall undoubtedly be one of the first issues to be examined in the case of a possible personal data protection incident and control of the entity by the national supervisory authority.

One of the main conclusions from the above considerations is that before moving to more advanced solutions, lawyers who want to implement LegalTech solutions in their offices or legal departments should verify whether they use the simplest IT tools in a full and correct manner and whether the operational structure of the organization is suitable for taking another step forward in terms of modernization. It seems that lawyers falsely presume that they and their employees have the necessary competences in this area.

\section{LegalTech 2.0}

\subsection{General Remarks}

LegalTech 2.0 aims to replace lawyers in many of their activities, by having the machine assimilate some of the knowledge or legal processes. Thus, the technology in question does not only serve the purpose of streamlining everyday tasks by improving the efficiency of processes and work organization, but it is also intended to utilize technological potential to perform this work. LegalTech 2.0 solutions include i.a. e-discovery, document management automation software, contract analysis by Artificial Intelligence (AI), legal expert systems (i.e. chatbots), the use of Big data analytics to formulate legal arguments, predict the outcome of a hearing, and even business intelligence. Although the current state of Natural Language Processing (NLP) technology does not allow for high-quality understanding 
and processing of legal text ${ }^{13}$, it is predicted that in the future similar, activities of summarizing and editing basic legal texts will be possible. Compared to the previous LegalTech 1.0 category, these are more advanced disruptive technologies that nowadays are only partially used by law firms and legal departments due to their sometimes high cost and lack of overall trust on the part of lawyers. The second most important reason for their slow adoption is the lack of initiative on the part of lawyers themselves to implement such solutions and use them on a regular basis.

Before analyzing different solutions, it is worth noting that LegalTech 2.0 has great potential in terms of enhancing access to justice, especially for those who do not choose the services of law firms either because they cannot afford them or because the case involves a small amount of money (e.g. an unpaid invoice or unreturned deposit for an apartment). As C. Christensen points out, innovations usually fill the downstream gap in the first place ${ }^{14}$. Understanding this phenomenon usually reassures those who fear for the future of themselves and their law firm colleagues. This thesis is confirmed by the position occupied in the market by alternative legal service providers (ALSPs) ${ }^{15}$. Their services, which are massively automated and aggressively promoted, are offered at affordable prices and often do not compete directly with law firms, which prefer to engage in more complex, revenue-generating activities. However, this does not preclude that the limit of the ALSP's range of services will continue to shift to include more and more complex services. An example is a platform offering a number of contracts for start-ups, which the customers personalize themselves using a form designed for this purpose and, if necessary, seeks advice from a virtual assistant. With the arrival of a new generation of employees, including managers ${ }^{16}$, such solutions, focused on the quality of User Experience (UX), must be adopted by law firms, otherwise all

13 Kevin D. Ashley, Artificial Intelligence and Legal Analytics: New Tools for Law Practice in the Digital Age (Cambridge University Press 2017) 4.

14 Clayton Christensen, The Innovator's Dilemma: When New Technologies Cause Great Firms to Fail. Boston (MA: Harvard Business School Press 1997) 215.

15 An ALSP's market presence depends largely on the level of regulation of the legal profession in a particular state.

16 The U.S. Bureau of Labor Statistics predicts that by 2030, so-called millenials will make up 75\% of the workforce; see: Jeff Schwartz and Bill Pelster, 'Global Human Capital Trends 2014: Engaging the 21st-century workforce' < https://www2.deloitt e.com/us/en/insights/focus/human-capital-trends/2014/hc-trends-2014-introductio n.html/\#endnote-sup-10> accessed 25 April 2021. 
customers will turn to ALSPs, even though they may be presumed to provide services of lower quality ${ }^{17}$.

\subsection{Document Management Automation Software}

Much less popular are programs for document automation, workflow management ${ }^{18}$ in a law firm or sophisticated Customer Relationship Management (CRM) systems ${ }^{19}$ - tailored specifically to the needs of a given law firm. Thanks to these solutions, which have been used by entities from other sectors for over 15 years, clients have the possibility to track the progress of work on their case, including monitoring of the time spent by the law firm on assigned tasks, or exchange of documents and correspondence. In case of more advanced programs, the lawyer can manage e.g. general meetings online, send documents for electronic signature (when CRM has an integrated certified signature system), work on documents or issue invoices. Due to the fact that these types of solutions are cloud-based, multiple users can have both passive access as well as active participation in creating and editing documents at the same time, thus transforming CRM into an interactive platform. Such tools, in their more elaborated version, often are global in nature and successfully replace many other tools, such as instant messaging or e-billing ${ }^{20}$.

In the context of LegalTech 2.0, one should also not forget about an extremely important automation process in the management of the docu-

17 It is worthwhile to refer to the considerations of R. Susskind on the right to a court in the context of the need to provide citizens with adequate tools to determine their rights and possible scenarios of action in the event of popularization of online courts; see: Richard Susskind, Online Courts and the Future of Justice (Oxford University Press 2019) 121.

18 The term can be understood in two ways: in a broad sense (as a way of information flow between various objects involved in its processing) and in a strict sense (as a way of document flow between employees performing a certain algorithmic set of activities); see dictionary entry: Wikipedia, 'workflow' $<$ https://pl.wikipedia. org/wiki/Workflow> accessed 25 April 2021.

19 For more on CRM, see Ahmad M. Zamil, 'Customer Relationship Management: A Strategy to Sustain the Organization's Name and Products in the Customers' Minds' (2011) 3 European Journal of Social Sciences 451-459.

20 On e-billing see more: Christine Legner and Kristin Weber, 'Electronic bill presentment and payment' <www.researchgate.net/publication/221408047_Electron ic_Bill_Presentment_and_Payment/link/55746c1f08ae7536374fee56/download> accessed 25 April 2021. 
ments owned. Despite appearances (and some advertising slogans), it is not limited to purchasing software licenses only. In fact, the first step that law firms and legal departments should start with is to systematize their documents (knowledge management) and develop templates containing various modifications (e.g. potential contractual clauses). The law firm should also perform an audit of the documents to be automated, as it is possible that, for example, it may be sufficient to store some more untypical contracts which require a high degree of personalization and are rarely used, in a structured version, without the need to enter them into a document automation program. The aforementioned task cannot be entrusted solely to administrative staff or lower-rank lawyers but requires the involvement of more experienced law firm partners/associates as well. This allows you to place in the system the highest quality template documents, providing for all (or almost all) possible objections/modifications/comparisons. Only after this step has been completed should the work with the IT program begin.

This first step can be an opportunity for many people to reorganize their e-library of documents, rethink internal processes, unify the style of letters, or even implementation of further innovations, e.g. by using legal design techniques to simplify the form of legal communication ${ }^{21}$. The very introduction of pre-designed templates into the system can also be laborious, requiring meticulousness and equivalent training by the solution provider. Therefore, it is recommended that it be entrusted to an administrative employee familiar with law office procedures.

\subsection{Chatbots}

The above mentioned chatbots constitute a LegalTech 2.0 solution whose implementation could be a game-changer for numerous law firms. R. Susskind defines them as computer applications containing a representation of knowledge and expertise used to solve problems, advise or perform other various activities, in a manner analogous to that of humans ${ }^{22}$. Although they were invented de facto in the 1980s, their potential was not

21 On legal desing see, e.g: Véronique Fraser and Jean-François Roberge, 'Legal Design Lawyering: Rebooting Legal Business Model with Design Thinking' (2016) 16 Prepperdine Dispute Resoluton Law Journal 303-316; Roman M. Yankovskiy, Legal Design: New Challenges and New Opportunities (2019) 5 Zakon 76-86

22 Richard Susskind, The End of Lawyers? Rethinking the Nature of Legal Services, (Oxford 2010), p. 120. 
initially recognized in the legal sector (mainly due to the competition of the Internet era). It is only recently that the possibilities of legal expert systems have been used by both public and private organizations ${ }^{23}$. Nowadays, the application of these systems is extremely wide and easily available on the market, e.g. when evaluating compliance of company's practices with GDPR. For example, the system created by an expert in the form of a decision tree (mind mapping), asks questions directly to the client and, step by step, leads to final conclusions and recommendations ${ }^{24}$.

It should be noted that such a result can be achieved without the need for artificial intelligence. However, more complex systems that are powered by AI for the purpose of carrying out diagnosis also have promising applications, especially because of the self-learning process of the algorithms. Unfortunately, even state-of-the-art legal expert systems are not equal to legal analysis carried out by humans ${ }^{25}$. First, creating such a system is very laborious and requires top-level expertise, which is not financially rewarding due to rapidly changing legislation. Second, technologies developed on the basis of uncertain and incomplete information tend to be single-purpose rather than comprehensive ones. Third, manual reproduction of the law leads to a knowledge acquisition bottleneck, which itself is problematic as it does not reflect the complexity of legal provisions ${ }^{26}$. Moreover, the current state of technology does not allow to solve this important problem ${ }^{27}$. Therefore, nowadays we rather observe the alternative use of chatbot infrastructure to automate simple services preceding the

23 One of the more widely described applications of legal expert systems in the literature is BNA - a program of the British government used to evaluate applications of foreigners; see: Kevin D. Ashley (n 285) 48 ; or Foley \& Lardner law firm's chatbot powered by artificial intelligence to analyze international operations' compliance with U.S. anti-corruption law, the Foreign Corrupt Practices Act - Michale Mills, 'Artificial Intelligence in Law: The State of Play, 2016, Part 3' $<$ https:/www.neotalogic.com/wp-content/uploads/2016/04/Artificial-Intelligence -in-Law-The-State-of-Play-2016.pdf> accessed 25 April 2021.

24 See Martin Hasal, Jana Nowaková, Khalifa Ahmed Saghair, Hussam Abdulla,Václav Snášel, Chatbots: Security, privacy, data protection, and social aspects $<$ https://onlinelibrary.wiley.com/doi/full/10.1002/cpe.6426> accessed 25 July 2021.

25 Kevin D. Ashley (n 13) 8.

26 On the knowledge acquisition bottleneck (i.e., the difficulty in acquiring knowledge from human experts or other resources) see e.g.: Mihai Boicu, Gheorghe Tecuci, Bogdan Stanescu, Gabriel C. Balan and Elena Popovici, 'Ontologies and the Knowledge Acquisition Bottleneck' <www.researchgate.net/publication/2285 49124_Ontologies_and_the_knowledge_acquisition_bottleneck/link/549dbfd20cf 2 fedbc31198ec/download $>$ accessed 25 April 2021.

27 Kevin D. Ashley (n 13). 9. 
legal service and to build the brand of an innovative law firm, e.g., by locating a simple chatbot on a website, which, as a result of asking a series of questions, obtains information allowing to redirect the client to the appropriate department of the law firm.

\subsection{Artificial Intelligence}

The legal community's hopes have been raised by the development of machine learning and $\mathrm{AI}^{28}$. Current AI-based software is successfully used to analyze large amounts of documents, e.g. in the due diligence process for mergers \& acquisitions (M\&A) or real estate. However, this solution is being used at the moment almost exclusively by large international law firms, due to its high cost and the large number of transactions that are necessary to leverage even partially the potential of AI. It is estimated that in order to teach the algorithm to properly distinguish the clauses (taking into account the differences in editing and terminology), 180-200 training contracts are needed. Lack of availability of multilingual training material for algorithms is one of the major obstacles for the development of these technologies on a larger scale, both geographically (so that they are applicable in other than English speaking markets) as well as by increasing the availability of ready-made solutions also to smaller law firms (reducing the cost of the solution through the economies of scale). Currently, the pioneers of such solutions, in order to enable their own development, most often start cooperation with law firms, providing them with a "semi-finished product", i.e. software with limited functionality of algorithms, counting on the improvement of algorithms along with their use, and justifying the price with other functionalities based on traditional programming, e.g. systematization and labeling of documents, possibility to co-edit and compare documents, operation management by assigning tasks (workflow management). However, despite the exclusivity of this solution, M\&A departments, due to, i.a., the use of popular data rooms, which force them to make the first step necessary to enable the use of the discussed software, such as dematerialization of documents, are still considered as the so called 'early adopters' in the use of LegalTech 2.0.

28 See Section VII Chapter 4 and 7. 


\subsection{Blockchain}

Blockchain ${ }^{29}$ - depending on the way of use - can be divided into three categories: 1.0, 2.0, and 3.0, and categorized accordingly within the respective LegalTech categories. Currently, this technology although promptly replaced but Blockchain 3.0, seems to be most often used in LegalTech 2.0 (which led to its inclusion in this subchapter). Regardless of this, it should be pointed out that due to its properties (i.e. security, transparency, preservation of chronology, immediacy, proof of work), it is a breakthrough technology for lawyers ${ }^{30}$. There are many initiatives aimed at leveraging blockchain capabilities for legal services. The best known and closest to law are definitely smart contracts - computerized transaction protocols executing the terms of a contract ${ }^{31}$. As these are addressed in separate chapters in this book, the applications that will be cited are of more niche character, yet they can still provide real convenience for lawyers.

This category includes the use of blockchain to maintain books and update entries in business registers - a legal obligation that entails numerous formalities involving the participation of a lawyer. The creation of dematerialized business registers covers in practice all sorts of company activities that are required to be recorded by national law, such as the register of shareholders, decisions of company bodies (e.g. the board of directors), or the register of employees ${ }^{32}$. In addition, company documents such as minutes of general meetings or written consultations of shareholders can be created and stored in a digital form.

Furthermore, blockchain can be used in a similar way to manage and protect intellectual property in which law firms are currently involved. It is possible to use this technology to record intellectual property rights,

29 For more on blockchain technology, see, e.g. Dariusz Szostek, Blockchain and the Law (1 ed., Nomos 2019).

30 See Yves Poullet and Hervé Jacquemin, 'Blockchain: une révolution pour e droit? (2018) 6748 Journal des tribunaux 801.

31 Nick Szabo, 'Smart Contracts', <www.fon.hum.uva.nl/rob/Courses/InformationI nSpeech/CDROM/Literature/LOTwinterschool2006/szabo.best.vwh.net/smart.co ntracts.html> accessed 25 April 2021.

32 Such obligations are required by French company law and their recording in blockchain technology has been enabled by law gradually in 2017 and 2019 - Ordonnance $\mathrm{n}^{\circ}$ 2017-1674 du 8 décembre 2017, also known as Ordonnance "blockchain", décret n²019-1118 du 31 octobre 2019 relatif à la dématérialisation des registres, des procès -verbaux et des décisions des sociétés et des registres comptables de certains commerçants 
as well as transactions involving works ${ }^{33}$. On the other hand, recording inventions by means of transcription in blockchain would solve a number of problems currently encountered, i.e. proof of priority. Moreover, blockchain would solve the problem of possible misappropriation attempts by a uniform traceability system that remains intact throughout the whole period of evolution and existence of the invention ${ }^{34}$.

\section{LegalTech 3.0}

Tools included in the most recent (for the time being) level of LegalTech are characterized by much greater independence than in the previous two categories. In their case, we are no longer dealing with mere automation, but with far-reaching autonomy of decisions. For obvious reasons, these solutions raise as much concern as hope. On the one hand, there is a futuristic vision of replacing lawyers with computer programs or the risk of uncontrolled operation of IT solutions that affect our lives. On the other hand, there is a chance for jurists to focus on really complicated cases requiring experience and to leave the simple and repetitive ones to digital assistants.

LegalTech 3.0 means, above all, solutions based on artificial intelligence and advanced algorithms using machine learning. However, as it has already been indicated in the opening chapter of this monograph, in these cases, the decisions are made by the system on the basis of independently acquired data and self-learning, while the final decision may be made directly by the IT system, without any control, as well as previously accepted by a human.

At this stage, only experiments and first attempts to implement similar solutions are being carried out. Most likely, however, the real boom will

33 Monika A. Górska and Lena Marcinowska, 'Czy blockchain namiesza w umowach dotyczących własności intelektualnej?' <https://newtech.law/pl/blockcha in-namiesza-umowach-dotyczacych-wlasnosci-intelektualnej/> accessed: 25 April 2021; for more on the use of blockchain for the protection and management of intellectual property rights, see B. P. Singh and Anand Kumar Tripathi, 'Blockchain Technology and Intellectual Property Rights' (2019) 24 Journal of Intellectual Property Rights 41-44; Gonenc Gürkaynak, Ilay Yılmaz, Burak Yeşilaltay and Berk Bengi, 'Intellectual Property Law and Practice in the Blockchain Realm' (2018) 34 Computer Law \& Security Review 847-862.

34 Guy Canivet, '«Preuve et Blockchain», présentation de la table ronde' (2019) 2 Dalloz IP/IT 201973. 
come only with the development of the so-called strong (general) artificial intelligence, i.e. one characterized by self-awareness ${ }^{35}$.

It seems that lawyers will (and should) approach the implementation of solutions based on LegalTech 3.0 with extreme caution. Due to the significant degree of their independence, full control of these solutions will be impracticable, which in practice will translate into a number of legal and ethical problems: from liability for the actions of the said software, through potential difficulties in respecting professional secrecy (attorneys, notaries, etc.), to the validity of such actions, for example: if the law restricts the group of persons entitled to lodge a cassation appeal to professional attorneys, does its preparation, affixing a secure electronic signature (assuming that the law of a given state allows such a solution) and sending by an AI, which was, however, launched by a professional attorney, meet the above-mentioned requirements?

\section{Summary}

The use of LegalTech solutions on a daily basis, although they are intended to facilitate and streamline the work of lawyers, also raises and will undoubtedly raise many doubts and challenges. The source of these doubts will often be hidden in the lack of prior consideration of the legitimacy of implementing certain solutions or misunderstanding of their actual nature and purpose. As a result, there are a few general reflections summarizing the previous considerations, which at the same time can serve as a kind of guidance at the stage of implementing such solutions in modern law firms.

First and foremost, all lawyers using LegalTech systems should start implementing any new solution by analyzing their needs and deciding whether this solution will actually be useful. For example, in the case of a law firm whose business is based primarily on court cases, the priority will be to systematize and automate letters rather than to invest in tools for conducting remote meetings of shareholders of companies. In practice, it may turn out that such a tool will not be used at all, and the money spent, objectively speaking, will be wasted. Ultimately, this may even discourage a given lawyer from using LegalTech solutions in the future.

Second, it is essential to learn the basics of any software being used before implementing new, more advanced solutions. A lawyer who is not

35 Aleksander Chłopecki, Sztuczna inteligencja - szkice prawnicze i futurologiczne (2nd edn, Wydawnictwo C.H. Beck 2021) 5. 
proficient in using a "traditional" text editor is unlikely to be able to take full advantage of the potential of cloud solutions that allow real-time document sharing and editing. The digitization of a law firm should therefore be adapted both to the real level of its employees and to the expectations of clients.

Third, it's important to remember that technological deployment is only a part of the way to modernizing law firms and in-house offices. An innovative approach should become a certain standard rather than just a passing trend. Therefore, it is advisable to match technology solutions to real needs and to place emphasis on engaging the entire team to promote participation in finding solutions to the concerns of a given team, i.e. suboptimal management of knowledge or time. Naturally, keeping abreast of technology trends, raising curiosity about its real applications in the legal sector, as well as experimentation are encouraged. It is the commitment of the entire law firm team, not the occasional initiatives of individual LegalTech enthusiasts, that will lead to a more efficient digital transformation of the law firm and the firm's legal department.

Lastly, using even the most advanced IT solutions does not relieve us, lawyers, from the obligation to constantly improve our skills and qualifications. LegalTech in a law firm should be a motivation to take the quality of our services to the next level, but not an excuse for future laziness. 
